\title{
Effect of Supplementation of Glutathione and $\alpha$-Tocopherol in Tris and Skim Milk Based Extenders on Motility Parameters of Ram Semen at Refrigeration Temperature
}

\author{
Sangamesh Muniyappanavar ${ }^{1}$, M. K. Tandle 2 , P. T. Vinay ${ }^{2}$, R. G. Bijurkar ${ }^{2}$, \\ M. D. Suranagi ${ }^{2}$, Shrikant Kulkarni ${ }^{2}$ and B. Bhagavantappa ${ }^{2}$ \\ ${ }^{1}$ Veterinary Officer, Belagavi, Karnataka, India \\ ${ }^{2}$ KVAFSU, Bidar, Karnataka, India \\ *Corresponding author
}

\begin{abstract}
A B S T R A C T
The present study was conducted to evaluate the effect of supplementation of glutathione and $\alpha$-tocopherol in TRIS and skim milk based extenders on motility parameters of ram semen at refrigeration temperature. The research findings of the present study shown that, addition of glutathione improved motile sperm and reduced immotile sperm percentage than $\alpha$-tocopherol in skim milk than TRIS egg yolk based extenders. Addition of glutathione improved rapid progressive sperm percentage than $\alpha$-tocopherol in TRIS egg yolk than skim milk based extenders. Addition of $\alpha$ tocopherol in TRIS egg yolk reduced slow progressive sperm percentage, whereas improved in skim milk based extenders as compared to addition of glutathione. Addition of either glutathione or $\alpha$-tocopherol did not reduce the non-progressive sperm percentage in skim milk and TRIS egg yolk based extenders. The volume of semen (Mean \pm SE) ranged from $0.83 \pm 0.04$ to $0.94 \pm 0.03 \mathrm{~mL}$ having creamy colour. The mass activity of semen samples was with ++++ for all semen samples in NARI Suwarna strain of sheep. The addition of glutathione in skim milk based extender improved motile sperm percentage than TRIS egg yolk extender at $72 \mathrm{~h}$ of refrigeration. The addition of glutathione increased rapid progressive sperm percentage at $72 \mathrm{~h}$ of refrigeration in TRIS egg yolk than skim milk based extender.
\end{abstract}

\section{Keywords}

$\alpha$-Tocopherol,

Extenders,

Motility parameters,

TRIS egg yolk

Article Info

Accepted:

25 February 2020

Available Online:

10 March 2020

\section{Introduction}

The present study was carried out with the objective to study the effect of addition of glutathione $5 \mathrm{mM} / \mathrm{mL}$ and $\alpha$-tocopherol $2 \mathrm{mM} / \mathrm{mL}$ in TRIS-egg yolk and skim milk based extenders for preservation of semen under refrigeration temperature at $0,24,48$ and $72 \mathrm{~h}$.

The NARI Suwarna, a new strain of Deccani sheep is capable of producing twin lambs due to the presence of $F e c B$ gene. The main aim of processing semen is to preserve fertile life 
of the spermatozoa for longer time and to increase semen volume so that the genetic merit of rams can be utilized maximum (Maxwell and Watson, 1996). Many kind of extenders like TRIS-egg yolk, skim milk, sodium citrate-egg yolk, coconut milk etc. are used in addition to many other traditional extenders successfully in preserving ram semen (Hegedusova et al., 2012). El-Gaafary (1987) suggested that skim milk extender was found to be a good medium for preserving the fertilizing capacity of ram spermatozoa for three $\mathrm{h}$ at $5^{\circ} \mathrm{C}$ during storage. Kaimal (2015) concluded that skimmed milk powder extender (SMPE) was better than TRIS egg yolk extender (TEYE) and sodium citrate egg yolk extender (SCEYE). Also Kadaganchi (2017) concluded that skim milk fructose extender (control) had better ability in preserving sperm motility in comparison with extenders supplemented with glutathione or honey at $0,24,48$ and $72 \mathrm{~h}$ at refrigeration temperature for preservation of NARI Suwarna ram semen by CASA.

The Computer-Assisted-Semen-Analysis (CASA) can be considered as an efficient, reliable, repeatable and precise tool to evaluate fertility as well as the physiological differences in sperm motion characteristics in different age and genetic groups (Kathiravan et al., 2011).

The supplementation of glutathione (GSH) to ram sperm diluents improved viability, sperm motility and protected plasma membrane characteristics of the spermatozoa from free radical damage (Triwulanningsih et al., 2003) and improved sperm survival following $6 \mathrm{~h}$ of storage at $5^{\circ} \mathrm{C}$. Addition of glutathione (5 $\mathrm{mM}$ ) in TRIS egg yolk extender provided the best quality in local ram semen (Solihati et $a l .$, 2018). Solouma (2013) concluded that supplementation of GSH $(0.4,0.8$ and 1.2 $\mathrm{mM}$ ) in TRIS egg yolk extender for preservation of Sohagi ram semen significantly $(\mathrm{P}<0.05) \quad$ increased the percentages of sperm motility, sperm livability and intact acrosome.

Vitamin $\mathrm{E}$ is the first line of defence against the peroxidation of the polyunsaturated fatty acid of membranous phospholipids structure because of its lipo-solubility. $\alpha$-tocopherol is an antioxidant found in the sperm cell membrane and acts by quenching free radicals and neutralizing hydrogen peroxide, hence breaking a chain-reactions that produce lipid peroxide and protect the plasma membrane from the damage caused by ROS (Lampiao, 2012).

Kheradmand et al., (2006) concluded that supplementation of egg-yolk/citrate buffer with 1 or $2 \mathrm{mg}$ of vitamin $\mathrm{E}$ improved the motility and sperm membrane integrity up to $48 \mathrm{~h}$ during storage at $5^{\circ} \mathrm{C}$ in chilled ram semen.

\section{Materials and Methods}

The research study was carried out on five sexually mature NARI Suwarna rams maintained at the Department of Veterinary Gynaecology and Obstetrics, Veterinary College, Nandinagar, Bidar from November 2018 to April 2019 with objective to evaluate the effect of addition of glutathione $5 \mathrm{mM} / \mathrm{mL}$ and $\alpha$-tocopherol $2 \mathrm{mM} / \mathrm{mL}$ in TRIS-egg yolk and skim milk based extenders for preservation of semen under refrigeration temperature at $0,24,48$ and $72 \mathrm{~h}$. All the five rams were maintained under uniform conditions and reared under semi intensive housing system. The rams were kept in a single flock and routine vaccination and deworming performed as per schedule. The rams were fed @ with 200 g concentrate, allowed free grazing of $7-8 \mathrm{~h}$ daily and provided ad libitum drinking water throughout the day. The semen was collected with an artificial vagina (AV) from all the 
five NARI Suwarna rams twice in a week by standard procedure. A total of 60 ejaculates were collected, 12 from each of the five mature NARI Suwarna rams twice a week. The ejaculated semen volume was measured in milliliters (mL) $(0.1 \mathrm{~mL}$ accuracy) and color was assessed by naked eyes immediately after collection in the graduated collecting tube. The samples with abnormal colour and semen samples with presence of dust, urine, fecal particles, vaseline etc were rejected.

\section{Semen dilution}

All the four semen extenders were prepared one day before the semen collection and stored at refrigeration temperature and thawed to room temperature $\left(37^{\circ} \mathrm{C}\right)$ in a water bath at the time of semen dilution. All the semen samples from five rams pooled, divided into six aliquots and diluted with six different extenders (1:60) at room temperature as mentioned below.

Preparation of six different semen
extenders

\section{Tris-egg yolk extender (TEYE)}

A buffer solution containing Tris $(2.4 \mathrm{~g})$, fructose (1g) and citric acid (1.4g) was prepared by adding each ingredient to the double distilled water in a beaker. $15 \%(\mathrm{v} / \mathrm{v})$ $15 \mathrm{~mL}$ egg yolk was added to it and $100 \mathrm{mg}$ Streptomycin sulphate, 1 lakh IU crystalline Penicillin mixed properly by using magnetic stirrer for 3-5 min. Double distilled water was added to make the final volume $100 \mathrm{~mL}$.

\section{Tris-egg yolk glutathione extender (TEYGE)}

Reduced glutathione $5 \mathrm{mM} / \mathrm{mL}$ were added to TEYE before making it to final volume $100 \mathrm{~mL}$ by adding Double distilled water.

\section{Tris-egg yolk $\alpha$-tocopherol extender}

$\alpha$-tocopherol at $2 \mathrm{mM} / \mathrm{mL}$ were added to TEYE before making it to final volume $100 \mathrm{~mL}$ by adding Double distilled water.

\section{Skim milk extender (SME)}

The extender was prepared by adding skim milk powder $(10 \mathrm{~g})$ and double distilled water $(80 \mathrm{~mL})$ heating to $95^{\circ} \mathrm{C}$ for $10 \mathrm{~min}$ and then cooled to room Temperature. Later $0.9 \mathrm{~g}$ Fructose, 100mg Streptomycin sulphate, 1 lakh IU crystalline Penicillin was added. Then volume was made to $100 \mathrm{~mL}$ by adding double distilled water.

\section{Skim milk reduced glutathione extender (SMGE)}

Reduced glutathione $5 \mathrm{mM} / \mathrm{mL}$ were added to SME before making it to final volume $100 \mathrm{~mL}$ by adding Double distilled water.

\section{Skim milk $\alpha$-tocopherol extender}

$\alpha$-tocopherol at $2 \mathrm{mM} / \mathrm{mL}$ were added to SME before making it to final volume $100 \mathrm{~mL}$ by adding Double distilled water.

The chilled diluted semen was assessed by CASA 2000 Biovis (Expert Vision labs Pvt. Ltd. Mumbai, India) at 0, 24, 48 and $72 \mathrm{~h}$ of storage as described below. A drop of diluted semen was taken on clean grease free prewarmed glass slide at $36^{\circ} \mathrm{C}$ and covered by a cover slip and was focused under phase contrast microscope of $100 \mathrm{X}$ magnification. CASA Biovis software was turned on and after fine adjustment clicked on option capture which captured around 60 frames/minute and analysed automatically for various velocity and motility parameters. The data obtained from research was statistically analysed by using SAS software version 9.3 . 


\section{Results and Discussion}

The volume of semen (Mean \pm SE) ranged from $0.83 \pm 0.04$ to $0.94 \pm 0.03 \mathrm{~mL}$ having creamy colour. The mass activity of semen samples was with ++++ for all semen samples in NARI Suwarna strain of Deccani sheep (Table 1). None of the samples noticed presence of foreign bodies in neat semen.

The motile sperm percentage (Mean \pm SE) was $97.79 \pm 0.46, \quad 90.30 \pm 1.41, \quad 84.68 \pm 1.61$ and $75.13 \pm 1.72$ higher in SMGE at 0, 24, 48 and $72 \mathrm{~h}$ of refrigeration whereas $81.20 \pm 1.78$ and $70.50 \pm 1.99$ lower in SME at 48 and $72 \mathrm{~h}$ and $95.69 \pm 0.80$ and $88.79 \pm 1.38$ in TEYE at 0 and $24 \mathrm{~h}$ of refrigeration respectively (Table 2 ). Further, irrespective of extender used the motile sperm percentage decreased significantly at 48 and $72 \mathrm{~h}$ when compared to $0 \mathrm{~h}$. Addition of glutathione improved motile sperm percentage than $\alpha$-tocopherol in skim milk than TRIS egg yolk based extenders at $72 \mathrm{~h}$ of refrigeration.

The rapid progressive sperm percentage (Mean \pm SE) was $73.96 \pm 1.17,59.37 \pm 1.95$ and $43.42 \pm 2.72$ higher in TEYGE at 0,48 and 72 $\mathrm{h}$ and $66.53 \pm 1.71$ in TEYTE at $24 \mathrm{~h}$ of refrigeration whereas lesser $67.90 \pm 1.61$, $58.09 \pm 1.92,46.11 \pm 3.07$ and $37.73 \pm 2.75$ in SME at $0,24,48$ and $72 \mathrm{~h}$ of refrigeration respectively (Table 3). Further, the rapid progressive sperm percentage decreased significantly in SMGE, SMTE, TEYE, TEYGE and TEYTE at 48 and $72 \mathrm{~h}$ when compared to $0 \mathrm{~h}$ of refrigeration. Further, SMGE and TEYGE differ significantly from SME at $48 \mathrm{~h}$ of refrigeration.

Addition of glutathione improved rapid progressive sperm percentage than $\alpha$ tocopherol in TRIS egg yolk than skim milk based extenders at $72 \mathrm{~h}$ of refrigeration.

\section{Neat semen characteristics of NARI Suwarna rams}

The volume of semen (Mean \pm SE) ranged from $0.83 \pm 0.04$ to $0.94 \pm 0.03 \mathrm{~mL}$ having creamy colour. The mass activity of semen samples was with ++++ for all semen samples in NARI Suwarna strain of Deccani sheep. None of the samples noticed presence of foreign bodies in neat semen. Similarly, Kadaganchi (2017) reported that semen volume ranged from $0.90 \pm 0.08$ to $1.15 \pm 0.18$ $\mathrm{mL}$, all the semen samples were creamy in colour and mass activity score ranged from $4.00 \pm 0.82$ to $4.83 \pm 0.37$ in NARI Suwarna strain of Deccani sheep. In addition, Nancy (2018) reported that semen volume (Mean \pm S.E) ranged from $0.89 \pm 0.01$ to $1.14 \pm 0.04 \mathrm{~mL}$, mass activity score (Mean \pm S.E) ranged from $4.0 \pm 0.15$ to $4.8 \pm 0.13$ and the creamy white to creamy in colour in NARI Suwarna strain of sheep.

The present finding supports the values mentioned Pervage et al., (2009) who reported semen volume of $0.86 \mathrm{~mL}$ of semen in native breed of sheep. Ismaya et al., (2012) also noticed semen volume $0.89 \mathrm{~mL}$ and semen colour varied from milky to thick creamy. In contrast, Rajashri et al., (2017) reported semen volume as $0.63 \pm 0.27 \mathrm{~mL}$ in Deccani rams which is lower than the present findings. The variations in the semen parameters in rams may be due to change in season and age (Benia et al., 2018). The variation in ejaculate volume could be due to breed, genotype differences, seasonal variations, frequency of semen collection, nutritional and health status of the animal. Also, the variations may be due to nutritional, physical, genetic and environmental effects (Toe et al., 1994), genetic and environmental changes (Gundogan et al., 2004) and seasonal variation (Rege et al., 2000) that can affect the semen quality. 
Table.1 Neat semen characteristics of NARI Suwarna rams

\begin{tabular}{|c|c|c|c|}
\hline Ram No. & Volume $(\mathbf{m L})($ Mean $\mathbf{\pm S E})$ & Colour & Mass activity $(+$ to ++++$)$ \\
\hline $\mathbf{1}$ & $0.85 \pm 0.05$ & Creamy & ++++ \\
\hline $\mathbf{2}$ & $0.94 \pm 0.03$ & Creamy & ++++ \\
\hline $\mathbf{3}$ & $0.83 \pm 0.04$ & Creamy & ++++ \\
\hline $\mathbf{4}$ & $0.90 \pm 0.03$ & Creamy & ++++ \\
\hline $\mathbf{5}$ & $\mathbf{0 . 9 1} \pm \mathbf{0 . 0 4}$ & Creamy & ++++ \\
\hline
\end{tabular}

Table.2 Motile sperm percentage (Mean \pm SE) in semen diluted with various extenders at 0,24 , 48 and $72 \mathrm{~h}$ of storage at refrigeration temperature

\begin{tabular}{|c|c|c|c|c|}
\hline Extenders & $\mathbf{0} \mathbf{h}$ & $\mathbf{2 4} \mathbf{h}$ & $\mathbf{4 8} \mathbf{h}$ & $\mathbf{7 2}^{\mathrm{h}}$ \\
\hline SME & $96.54^{\mathrm{a}} \pm 0.59$ & $88.89^{\mathrm{ab}} \pm 1.38$ & $81.20^{\mathrm{b}} \pm 1.78$ & $\mathbf{7 0 . 5 0}^{\mathbf{c}} \pm \mathbf{1 . 9 9}$ \\
\hline SMGE & $97.79^{\mathrm{a}} \pm 0.46$ & $90.30^{\mathrm{ab}} \pm 1.41$ & $84.68^{\mathrm{b}} \pm 1.61$ & $\mathbf{7 5 . 1 3}^{\mathbf{c}} \pm \mathbf{1 . 7 2}$ \\
\hline SMTE & $96.85^{\mathrm{a}} \pm 0.52$ & $89.77^{\mathrm{ab}} \pm 1.22$ & $82.56^{\mathrm{b}} \pm 1.67$ & $\mathbf{7 4 . 1 3}^{\mathbf{c}} \pm \mathbf{1 . 9 8}$ \\
\hline TEYE & $95.69^{\mathrm{a}} \pm 0.80$ & $88.79^{\mathrm{ab}} \pm 1.38$ & $81.50^{\mathrm{b}} \pm 1.79$ & $\mathbf{7 1 . 0 4}^{\mathbf{c}} \pm \mathbf{2 . 0 9}$ \\
\hline TEYGE & $97.19^{\mathrm{a}} \pm 0.61$ & $90.13^{\mathrm{ab}} \pm 1.18$ & $83.42^{\mathrm{b}} \pm 1.20$ & $\mathbf{7 2 . 8 6}^{\mathbf{c}} \pm \mathbf{2 . 1 2}$ \\
\hline TEYTE & $\mathbf{9 6 . 5 5}^{\mathrm{a}} \pm \mathbf{0 . 6 8}$ & $\mathbf{8 8 . 8 5}^{\mathrm{ab}} \pm \mathbf{1 . 2 5}$ & $\mathbf{8 2 . 8 7}^{\mathbf{b}} \pm \mathbf{1 . 7 7}$ & $\mathbf{7 1 . 5 9}^{\mathbf{c}} \pm \mathbf{2 . 4 3}$ \\
\hline
\end{tabular}

Note: SME: Skim Milk Extender, SMGE: Skim Milk Glutathione Extender, SMTE: Skim Milk $\alpha$-Tocopherol Extender, TEYE: Tris Egg Yolk Extender, TEYGE: Tris Egg Yolk Glutathione Extender, TEYTE: Tris Egg Yolk $\alpha$ Tocopherol Extender.

Means with different superscripts differ significantly at $\mathrm{P}<0.05$.

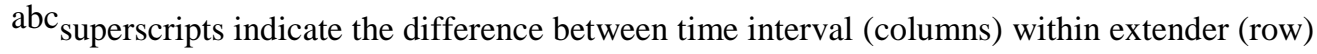

Table.3 Rapid progressive sperm percentage (Mean \pm SE) in semen diluted with various extenders at $0,24,48$ and $72 \mathrm{~h}$ of storage at refrigeration temperature

\begin{tabular}{|l|c|c|c|c|}
\hline Extenders & $\mathbf{0} \mathbf{h}$ & $\mathbf{2 4} \mathbf{h}$ & $\mathbf{4 8} \mathbf{~ h}$ & $\mathbf{7 2}^{\mathbf{~ h}}$ \\
\hline SME & $67.90^{\mathrm{a}} \pm 1.61$ & $58.09^{\mathrm{a}} \pm 1.92$ & $46.11^{\mathrm{Ab}} \pm 3.07$ & $\mathbf{3 7 . 7 3}^{\mathbf{b}} \pm \mathbf{2 . 7 5}$ \\
\hline SMGE & $71.03^{\mathrm{a}} \pm 2.04$ & $65.45^{\mathrm{ab}} \pm 1.44$ & $59.17^{\mathrm{Bb}} \pm 2.19$ & $\mathbf{4 1 . 6 5}^{\mathbf{c}} \pm \mathbf{2 . 4 5}$ \\
\hline SMTE & $71.65^{\mathrm{a}} \pm 1.90$ & $60.65^{\mathrm{ab}} \pm 2.05$ & $53.44^{\mathrm{ABb}} \pm 3.10$ & $\mathbf{3 5 . 4 6}^{\mathbf{c}} \pm \mathbf{2 . 6 4}$ \\
\hline TEYE & $69.99^{\mathrm{a}} \pm 1.32$ & $60.58^{\mathrm{ab}} \pm 1.53$ & $52.77^{\mathrm{ABb}} \pm 2.40$ & $\mathbf{3 9 . 8 3}^{\mathbf{c}} \pm \mathbf{2 . 5 6}$ \\
\hline TEYGE & $73.96^{\mathrm{a}} \pm 1.17$ & $65.76^{\mathrm{ab}} \pm 1.50$ & $59.37^{\mathrm{Bb}} \pm 1.95$ & $\mathbf{4 3 . 4 2}^{\mathbf{c}} \pm \mathbf{2 . 7 2}$ \\
\hline TEYTE & $\mathbf{7 0 . 3 8}^{\mathbf{a}} \pm \mathbf{1 . 5 6}$ & $\mathbf{6 6 . 5 3}^{\mathrm{ab}} \pm \mathbf{1 . 7 1}$ & $\mathbf{5 6 . 0 4}^{\mathbf{A B b}} \pm \mathbf{2 . 4 5}$ & $\mathbf{4 1 . 5 7}^{\mathbf{c}} \pm \mathbf{2 . 2 8}$ \\
\hline
\end{tabular}

Note: SME: Skim Milk Extender, SMGE: Skim Milk Glutathione Extender, SMTE: Skim Milk $\alpha$-Tocopherol Extender, TEYE: Tris Egg Yolk Extender, TEYGE: Tris Egg Yolk Glutathione Extender, TEYTE: Tris Egg Yolk $\alpha$ Tocopherol Extender.

Means with different superscripts differ significantly at $\mathrm{P}<0.05$

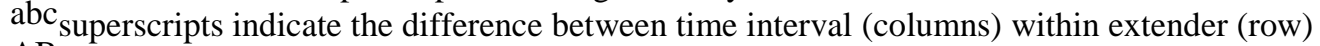

$\mathrm{AB}$ superscripts indicate the difference between extenders (rows) within time interval (column) 
Comparative evaluation of addition of glutathione $5 \mathrm{mM} / \mathrm{mL}$ or $\alpha$-Tocopherol $2 \mathrm{mM} / \mathrm{mL}$ in TRIS egg yolk and skim milk based extenders for preservation of semen under refrigeration temperature at 0,24 , 48 and $72 \mathrm{~h}$

On perusal of literature in respect of addition of glutathione or $\alpha$-Tocopherolas an additive in semen extenders and its evaluation by computer assisted semen analyzer (CASA) was not quoted previously by the research scholars and scientists. Hence, the present findings were compared with semen evaluation in different extenders with addition of glutathione or $\alpha$-Tocopherol as an antioxidant in domestic animals.

Motile sperm percentage $(\mathrm{Mean} \pm \mathrm{SE})$ in semen diluted with various extenders at 0 , 24,48 and $72 \mathrm{~h}$ of storage at refrigeration temperature

Irrespective of extender used the motile sperm percentage decreased significantly at 48 and $72 \mathrm{~h}$ when compared to $0 \mathrm{~h}$. Addition of glutathione improved motile sperm percentage than $\alpha$-tocopherol in skim milk than TRIS egg yolk based extenders at $72 \mathrm{~h}$ of refrigeration.

The present findings are in line Kadaganchi (2017) also concluded that values for motile sperm percentage varied from dilutor to dilutor with significant difference at $0,24,48$ and $72 \mathrm{~h}$ of preservation. The motile sperm percentage declined with increase in holding time in all extenders $(p<0.05)$. Among all extenders skim milk extender had better ability in preserving sperm motility in comparison with skim milk glutathione extender at 0,2448 and $72 \mathrm{~h}$ of semen storage at refrigeration temperature. Kubovicova et al., (2010) concluded that, supplementation of glutathione (but not caffeine) has a positive effect on ram spermatozoa fertilizing ability. In contrast, Nancy (2018) stated that motile sperm percentage was higher in TRIS egg yolk extender than skim milk based extender at 0 , 24, 48 and $72 \mathrm{~h}$ of preservation at refrigeration temperature. The motile sperm percentage declined with increase in holding time in all extenders $(\mathrm{P}<0.05)$.

The present research findings were supported by Uysal and Bucak (2007) who concluded that, oxidised glutathione $(5 \mathrm{mM})$ showed more positive effects than other concentrations of the supplements and controls (TRIS-based extender) in protecting sperm characteristics after the freeze-thawing process $(\mathrm{P}<0.001)$ of Akkaraman ram semen. Zeitoun et al., (2015) also concluded that 1 - 2 $\mathrm{mM} / \mathrm{mL}$ glutathione supplementation to ram semen extender during chilled storage enhanced sperm survival rate and reduced free radicals. Moreover, Solihati et al., (2018) concluded that glutathione level of $5 \mathrm{mM}$ in egg yolk TRIS extender provide the best quality of local ram semen.

Kheradmand et al., (2006) concluded that, supplementation of egg-yolk/citrate buffer with 1 or $2 \mathrm{mg}$ of vitamin $\mathrm{E}$ improved the motility and sperm membrane integrity up to $48 \mathrm{~h}$ during storage at $5^{\circ} \mathrm{C}$ in chilled ram semen. Azawi and Hussein (2013) concluded that, the addition of antioxidants such as vitamin $\mathrm{E}$ and vitamins $\mathrm{C}$ to semen preservation media could improve longevity and quality of cooled sperm in Awassi ram semen. Silva et al., (2013) found that Trolox (Vitamin E) addition to Tris-egg yolk at 60 and $120 \mathrm{mM}$ provides greater structural integrity (plasma membrane and mitochondria) and kinematics for ram spermatozoa.

Pour et al., (2013) reported that supplementation of $2 \mathrm{mg} / \mathrm{mL}$ vitamin $\mathrm{E}$ recommended for long term storage of Ghezel 
ram spermatozoa as it protects against the damages caused by reactive oxygen species such as hydrogen peroxide, superoxide anion and hydroxyl radicals. Kaimal (2015) stated that, sodium citrate egg yolk extender supplemented with vitamin $\mathrm{E}$ founds to be more superior to supplementation with vitamin $\mathrm{C}$ and control up to $72 \mathrm{~h}$ of preservation at refrigeration temperature in NARI Suwarna rams.

Zeitoun et al., (2015) concluded that, supplementing 5 IU Vitamin E or 1 - 2 mM glutathione to per $\mathrm{mL}$ semen extender during Najdi ram chilled storage enhanced sperm survival and reduced free radicals. Hamedani et al., (2016) reported that vitamin $\mathrm{E}$ has positive protection effects on the semen characteristics in chilled and frozen thawed and recommend to use $2 \mathrm{mM}$ of vitamin $\mathrm{E}$ in Tris extender for short and long term preservation of Zel ram spermatozoa.

Kurmi et al., (2018) recommended $2 \mathrm{mM}$ vitamin $\mathrm{E}$ was most effective as compared to $1 \mathrm{mM}$ vitamin $\mathrm{E}$ and control Tris dilutor in Chotanagpuri rams which supports the present research work.

\section{Rapid progressive sperm percentage (Mean \pm SE) in semen diluted with various extenders at $0,24,48$ and $72 \mathrm{~h}$ of storage at refrigeration temperature}

The rapid progressive sperm percentage decreased significantly in SMGE, SMTE, TEYE, TEYGE and TEYTE at 48 and $72 \mathrm{~h}$ when compared to $0 \mathrm{~h}$ of refrigeration. Further, SMGE and TEYGE differ significantly from SME at $48 \mathrm{~h}$ of refrigeration. Addition of glutathione improved rapid progressive sperm percentage than $\alpha$-tocopherol in TRIS egg yolk than skim milk based extenders at $72 \mathrm{~h}$ of refrigeration.

The present findings are supported by Kadaganchi (2017) who reported that values for rapid progressive sperm percentage differed from dilutor to dilutor but they vary with significant difference at 0,24 and $72 \mathrm{~h}$ however, differed non-significantly between 24 and $48 \mathrm{~h}$ when compared to present study where they vary non-significantly. The rapid progressive sperm percentage decreased with increase in storage time in all extenders. Further, Nancy (2018) also stated that, rapid progressive sperm percentage was significantly higher in TRIS based extender and lower in skim milk based extender at 24, 48 and $72 \mathrm{~h}$ of storage. The rapid progressive sperm percentage decreased with increase in storage time in all extenders.

In conclusion, the volume of semen (Mean \pm SE) ranged from $0.83 \pm 0.04$ to $0.94 \pm 0.03 \mathrm{~mL}$ having creamy colour. The mass activity of semen samples was with ++++ for all semen samples in NARI Suwarna strain of sheep. The addition of glutathione in skim milk based extender improved motile sperm percentage than TRIS egg yolk extender at $72 \mathrm{~h}$ of refrigeration. The addition of glutathione increased rapid progressive sperm percentage at $72 \mathrm{~h}$ of refrigeration in TRIS egg yolk than skim milk based extender.

\section{References}

Azawi, O. I. and Hussein, E. K., 2013. Effect of vitamins $\mathrm{C}$ or $\mathrm{E}$ supplementation to Tris diluent on the semen quality of Awassi rams preserved at $5^{\circ} \mathrm{C}$. Vet. Res. Forum, Pp. 157- 160.

Benia, A.R., Saadi, M.A., Ait-Amrane, A., Belhamiti, T.B., Selles, S.M.A. and Kaidi, R., 2018. Effect of season and age on main characteristics of sperm production in the Ouled-Djellal rams. Livestock Research for Rural Development, 30: 1-4.

El-Gaafary, M. N. S. A., Chamberlain, A. G., and Axford, R. F. E., 1987.Survival rate and fertility of chilled ram semen 
supplemented with prostaglandin F2, Anim. Breed. Abstr., No. 2196.

Gundogan, M., Tekerli, M., Ucar, M. and Turkmenoglu, I., 2003. Effect of diluents on motility of ram sperm during storage at $5^{\circ} \mathrm{C}$. Arch. Androl., 49: 69-75.

Hamedani, M., Tahmasbi, A. M., Naserian, A. A. and Ahangari, Y. J., 2016. Evaluation of vitamin $\mathrm{E}$ on microscopic parameters of chilled and frozen stored ram semen. Der Pharma Chemica, 8(6): 16-22.

Hegedusova, Z., Stolc, L., Louda, F., Cunat, L. and Vejnar, J., 2012. Effect of different extenders on ram sperm traits during storage. Actauniv. Agric. Etsilvic. Mendel. Brun., 6: 111-116.

Ismaya, I., Fiztpatrick, L. and Summers, P., 2012. In vitro motility, velocity and capacitation status of Merino ram spermatozoa. Animal Production, 14(2): 18

Kadaganchi, A., 2017. Evaluation of semen preserved at refrigeration temperature by computer assisted semen analysis (CASA) of NARI Suwarna strain of sheep. MVSc Thesis. KVAFSU, Bidar, Karnataka.

Kaimal, P., 2015. Studies on reproductive traits, semen preservation at refrigeration temperature and its evaluation in NARI Suwarna strain of sheep. MVSc Thesis. KVAFSU, Bidar, Karnataka.

Kathiravan, P., Kalatharan, J., Karthikeya, G., Rengarajan, K. and Kadirvel, G., 2011. Objective sperm motion analysis to assess dairy bull fertility using computer- aided system-a review. Reproduction in Domestic Animals, 46(1): 165-172.

Kheradmand, A., Babaei, H. and Abshenas, J., 2006. Comparative evaluation of the effect of antioxidants on the chilledstored ram semen. Iran. J. Vet., Res., 7
:40-45.

Kubovičová, E., Riha, L., Makarevich, A. V., Apolen, D. and Pivko, J., 2010. Effect of different semen extenders and additives to insemination doses on ewe's pregnancy rates. Slovak Journal of Animal Science, 43(3): 118-122.

Kurmi, D. J., Sinha, M. P., Kumar, R., Hazarika, S. B., Dewry, R. K. and Gohain, S. 2018. Effect of vitamin E on the quality of frozen ram semen. Theriogenology, 8(1): 39-43.

Lampiao, F., Opperman, C. J., Agarwal, A. and Duplessis, S. S., 2012.Oxidative stress in male. Infertility, 225-235.

Maxwell, W. M. C. and Watson, P. F., 1996. Recent progress in the preservation of ram semen. Animal Reproduction Science, 42(1-4): 55-65.

Nancy, J., 2018. Supplementation of olive and almond oil in extenders for preservation of semen in NARI Suwarna strain of sheep. MVSc Thesis. KVAFSU, Bidar, Karnataka.

Pour, H. A., Tahmasbi, A. M. and Naserian, A. A., 2013. The influence of vitaminE on semen characteristics of Ghezel rams in during cooling and frozen process. Eur. J. Med. Res., 2: 94-99.

Pervage, S., Hassan, M. R., Ershaduzzaman, M. and Khandoker, M. A. M. Y., 2009. Preservation of liquid semen and artificial insemination in native sheep. $\mathrm{J}$. Bangladesh Agril. Univ., 7(2): 305-308.

Rajashri, M., Reddy, K. R., Kumari, G. A., Kumari, N. N. and Srinivas, G., 2017. Computer assisted semen analysis of Deccani ram semen presevability at $5^{\circ} \mathrm{C}$. Indian J. Anim. Res., 3450:1-6.

Rege, J. E., Toel, F.E., Mukasa-Mugerwa, S., Tembley, D., Amido, R. L., Baker. and Lahlou-Kassi, A., 2000. Reproductive characteristics of Ethiopian high land sheep. II. Genetic parameters of semen characteristics and their relationships with testicular measurements in ram 
lambs. Small Rumin. Res., 37(3):173187.

Solouma, G. M. A., 2013. The influence of adding glutathione on semen characteristics of Sohagi rams. Egyptian Journal of Sheep and Goat Sciences, 65(1243): 1-16.

Solihati, N., Rasad, S. D., Setiawan, R., Foziah, E. N. and Wigiyanti, E. T., 2018, February. Semen Quality of PostThawed Local Ram's in Tris-EggYolk Extender with Different Glutathione Level. In IOP Conference Series: Earth and Environmental Science, 119(1): 012034.

Toe, F., Lahlou-Kassi, A. and MukasaMugerwa, E., 1994. Semen characteristics of Ile-de-France rams of different age and physical condition.
Theriogenology, 42(2): 321-326. Triwulanningsih, E., Situmorang, P., Sugiarti, T., Sianturi, R. G. and Kusumaningrum, D. A., 2003. The effect of glutathione addition in sperm diluent on the quality of bovine chilled semen. JITV, 8 (2):9197.

Uysal, O. and Bucak, M. N., 2007. Effects of oxidized glutathione, bovine serum albumin, cysteine and lycopene on the quality of frozen-thawed ram semen. Acta Veterinaria Brno., 76(3): 383-390.

Zeitoun, M. M. and Al-Damegh, M. A., 2015. Effect of nonenzymatic antioxidants on sperm motility and survival relative to free radicals and antioxidant enzymes of chilled-stored ram semen. Open J. Anim. Sci., 5: 50-58.

\section{How to cite this article:}

Sangamesh Muniyappanavar, M. K. Tandle, P. T. Vinay, R. G. Bijurkar, M. D. Suranagi, Shrikant Kulkarni and Bhagavantappa, B. 2020. Effect of Supplementation of Glutathione and $\alpha$-Tocopherol in Tris and Skim Milk Based Extenders on Motility Parameters of Ram Semen at Refrigeration Temperature. Int.J.Curr.Microbiol.App.Sci. 9(03): 3063-3071. doi: https://doi.org/10.20546/ijcmas.2020.903.351 